\title{
Diagnosis of upper gastrointestinal lesions by endoscopy and its correlation with histopathology
}

\section{Santhi Kiran ${ }^{1}$, Y.R.Nagarjuna Kumar ${ }^{2}$}

\section{Associate Professor,ICARE institute of medical Sciences, B.C. Roy Medical College,Haldia,Culcutta,India}

2. Consultant Gastroenterologist,Endoviz Hospital,KPHB, Kukatpally,Hyderabad, Telangana

Corresponding Author “ Dr. D. Santhi Kiran, Associate Professor,ICare Institute of Medical Sciences, B.C. Roy Medical College, Haldia, Calcutta, India. Email id :Santhi.dronavalli@gmail.com

DOI : 10.47799/pimr.0802.21

\section{ABSTRACT}

Background: A wide spectrum of lesions can be encountered in the upper gastrointestinal tract (GIT) especially the stomach or the gastric cavity. Endoscopy forms a crucial diagnostic procedure; it gives good diagnostic results in non-neoplastic lesions, endoscopy with biopsy is usually done in neoplastic lesions where the differentiation of benign and malignant lesions cannot be made always.

Materials and Methods: This is a retrospective cum prospective study and the duration of this study was 4 yearsfrom January 2015 to December 2019 and the total number of endoscopic procedures performed was 3978. All patients with symptoms pertaining to the upper GIT where Upper Gastro-Intestinal Endoscopy (UGI Endoscopy) is useful in diagnosis were included in this study. All age groups and both the sexes were included. Biopsy was taken wherever there was an indication.

Results: In this study, a total of 3978 endoscopies were done, out of which 2689 patients were males (67.6\%) and 1289 were females (32.4\%), youngest patient age in this study was 13 years and the oldest was 79 years. Most of the lesions were located in the gastric cavity ( $48 \%$ - 1909 cases), followed by esophagus (34\%-1353 cases) and least among the three in the duodenum (18\%- 716 cases). Out of the 3978 lesions, 134 cases were diagnosed as carcinoma on endoscopy and they were confirmed by histopathological examination.

Conclusion: Endoscopy plays a very important role in the diagnosis of upper GIT lesions and it is incomplete without histopathological examination of biopsied tissue in cases of neoplastic lesions.

Keywords: Carcinoma, Endoscopy,biopsy, Stomach, Esophagus,Duodenum Helicobacter pylori,Gastritis

Introduction

Gastro-Intestinal tract commonly known as GIT is a big hollow organ with a lengthy anatomical distribution with rich blood supply and is divided into upper, middle and lower GIT. Upper GIT starts from mouth and is up to major papillae of the duodenum. Due to the long anatomical distribution of the GIT, it is prone to various kinds of congenital lesions, inflammatory disorders or diseases and neoplastic lesions mainly involving esophagus and stomach which are associated with high morbidity and mortality. To study about the disease in the patient, a gastroenterologist has to look inside the upper GIT to diagnose the disease, its progression and treatment, sometimes if there is neoplastic lesion, a biopsy sample from the lesion is required for histopathological correlation. Endoscopy is a procedure used to see and study the internal areas of the hollow organs or the cavities; it is done with local anesthesia or short general anesthesia in children and troublesome cases. In 1894 and 1895, Dr John Macintyre at Glasgow Royal Infirmary located in Scotland has succeeded in developing the self-illuminated endoscope as a part of his professional practice to investigate larynx [1]. In the year 1957, first ever fiber optic endoscope was invented by Basil Hirschowitz and Larry Curtiss [2]. Endoscopy is indicated to know the etiology in the patients with symptoms such as persistent and recurrent nausea and vomiting, abdominal pain, difficulty in deglutition and in the patients with bleeding in the GIT. Therapeutic endoscopic procedure is helpful in cauterization of a bleeding artery or vein; dilate a narrow esophagus due to congenital atresia or as a part of post-corrosive poison treatment, draw out or pull out an impacted foreign body swallowed by infants and children; to take out biopsy tissue for diagnosis and for polypectomy.

\section{AIM OF THE STUDY}

This study is done to know the clinical spectrum of lesions by endoscopic biopsies of upper gastrointestinal tract lesions and to on histopathology correlation between endoscopic diagnosis and histopathological diagnosis.

\section{MATERIALS AND METHODS}

This is a retrospective cum prospective study and the duration of this study was 4 years- from January 2015 to December 2019 and the total number of endoscopic procedures performed was 3978 . All patients with symptoms 
pertaining to the upper GIT where Upper Gastro-Intestinal Endoscopy (UGI Endoscopy) is useful in diagnosis were included in this study. All age groups and both the sexes were included. Lesions of the mouth and pharynx were excluded. All the patients posted for endoscopy were advised to fast overnight (atleast 8 hours) till the procedure, if the patients are on regular medications such as anti-hypertensive and anti-diabetics, they can take those medications with sips of water. Patients who were on anti-platelet medications were told to stop the medication 3 days prior to the procedure. Local anesthetic spray was used before the start of the procedure to make the pharynx numb. Endoscope was passed and the findings were noted. Biopsy was taken wherever there was an indication. After the procedure patients were shifted to the recovery room and kept under observation for any complications of the procedure. All the biopsy tissues taken as tiny fragments are fixed in $10 \%$ formalin and sent to the laboratory for processing, staining, histopathology examination and reporting. Special stains such as Warthin-Starry stain and Immuno HistoChemistry markers (IHC) were used to confirm the presence of Helicobacter pylori (H. pylori) and to know the histology type of malignancy respectively.

\section{RESULTS}

In this study, a total of 3978 endoscopies were done, out of which 2689 patients were males (67.6\%) and 1289 were females $(32.4 \%)$, youngest patient age in this study was 13 years and the oldest was 79 years. Age-wise distribution of the cases is shown in the Table 1.

Table 1: Age-wise distribution of the cases

\begin{tabular}{|c|c|c|}
\hline AGE GROUP & NUMBER OF CASES & PERCENTAGE (\%) \\
\hline $10-19$ years & 24 & $00.60 \%$ \\
\hline $20-29$ years & 624 & $15.70 \%$ \\
\hline $30-39$ years & 1529 & $38.43 \%$ \\
\hline $40-49$ years & 927 & $23.30 \%$ \\
\hline $50-59$ years & 583 & $14.66 \%$ \\
\hline $60-69$ years & 182 & $04.57 \%$ \\
\hline $70-79$ years & 109 & $02.74 \%$ \\
\hline TOTAL & 3978 & $100 \%$ \\
\hline
\end{tabular}

In this study, when the distribution of the lesions of the upper GIT was made, most of the lesions were located in the gastric cavity (48\% - 1909 cases), followed by esophagus (34\%-1353 cases) and least among the three in the duodenum (18\%- 716

Table 2: Distribution of the lesions on Endoscopy cases). Distribution of the lesions on endoscopy is shown in Table 2. Endoscopic findings of the upper GIT are tabulated in Table 3.

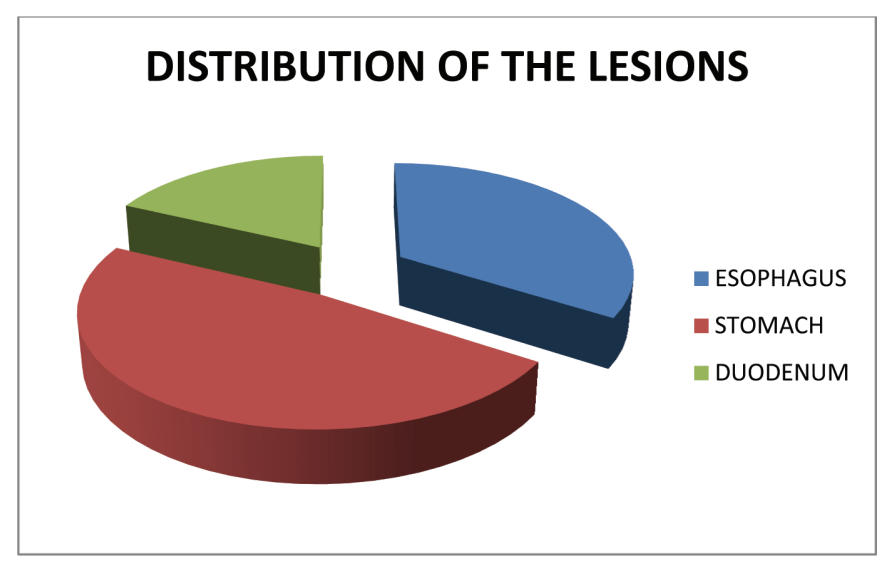


Santhi Kiran, et al

www. pimr.org.in

Table 3: Endoscopic Findings of Upper GIT

\begin{tabular}{|c|c|c|}
\hline ENDOSCOPIC DIAGNOSIS & NUMBER OF CASES & PERCENTAGE \\
\hline \multicolumn{3}{|l|}{ ESOPHAGUS } \\
\hline REFLUX ESOPHAGITIS (RE) & 649 & $16.32 \%$ \\
\hline HIATUS HERNIA WITH RE & 376 & $09.45 \%$ \\
\hline BARRETT'S ESOPHAGUS & 11 & $00.28 \%$ \\
\hline SQUAMOUS PAPILLOMA & 29 & $00.74 \%$ \\
\hline ESOPHAGEAL ULCER & 213 & $05.35 \%$ \\
\hline POLYP & 49 & $01.24 \%$ \\
\hline ADENOMA/CARCINOMA & 26 & $00.66 \%$ \\
\hline TOTAL & 1353 & \\
\hline \multicolumn{3}{|l|}{ STOMACH } \\
\hline \multirow{3}{*}{$\begin{array}{c}\text { NORMAL STUDY } \\
\text { CHRONIC NON-SPECIFIC GASTRITIS } \\
\text { HELICOBACTER PYLORI GASTRITIS (H.PYLORI) }\end{array}$} & 92 & $02.31 \%$ \\
\hline & 511 & $12.86 \%$ \\
\hline & 196 & $04.93 \%$ \\
\hline HYPERPLASTIC POLYP & 48 & $01.21 \%$ \\
\hline FUNDIC GLAND POLYP & 21 & $00.51 \%$ \\
\hline HIATUS HERNIA WITH GASTRIC ULCER & 469 & $11.79 \%$ \\
\hline GASTRIC ULCER & 480 & $12.08 \%$ \\
\hline GASTRO INTESTINAL STROMAL TUMOR (GIST) & 03 & $00.08 \%$ \\
\hline ADENOMA / CARCINOMA & 79 & $01.99 \%$ \\
\hline LYMPHOMA & 05 & $00.15 \%$ \\
\hline TOTAL & 1909 & \\
\hline \multicolumn{3}{|l|}{ DUODENUM } \\
\hline \multirow{2}{*}{$\begin{array}{l}\text { NORMAL DUODENUM } \\
\text { DUODENITIS }\end{array}$} & 205 & $05.15 \%$ \\
\hline & 381 & $09.52 \%$ \\
\hline CELIAC DISEASE & 87 & $02.18 \%$ \\
\hline GIARDIA & 08 & $00.20 \%$ \\
\hline $\begin{array}{l}\text { NEUROENDOCRINE TUMOR } \\
\text { CARCINOMA }\end{array}$ & 06 & $00.15 \%$ \\
\hline CARCINOMA & 29 & $00.73 \%$ \\
\hline TOTAL & 716 & \\
\hline GRAND TOTAL & 3978 & $100 \%$ \\
\hline
\end{tabular}

Out of the 3978 endoscopies, biopsies taken were 268 from the esophagus, 942 from the stomach or gastric cavity and 130 from the duodenum (Total biopsies $=1340-33.7 \%$ ). When

findings (HPE) was done, most of the endoscopic diagnosis was matched with the histopathology diagnosis (HPE) Table 4. comparison of the endoscopic findings with the histopathology 
Santhi Kiran, et al

www. pimr.org.in

Table 4: Comparison of Endoscopic biopsies with Histopathology Diagnosis

\begin{tabular}{|c|c|c|c|}
\hline LESION & ENDOSCPIC FINDINGS & HPE FINDINGS & $\begin{array}{c}\text { OTHER DIANOSIS } \\
\text { ON HPE }\end{array}$ \\
\hline Barrett's Esophagus & Barrett's Esophagus(n=11) & $\begin{array}{l}\text { Barrett's } \\
\text { Esophagus( } n=10)\end{array}$ & $\begin{array}{l}\text { Squamous Cell } \\
\text { Carcinoma }(n=1)\end{array}$ \\
\hline Squamous Papilloma & Squamous Papilloma(n=29) & $\begin{array}{l}\text { Squamous } \\
\text { Papilloma(n=29) }\end{array}$ & NIL \\
\hline Esophageal Ulcer & Esophageal Ulcer $(n=153)$ & $\begin{array}{l}\text { Esophageal } \\
\text { Ulcer(n=142) }\end{array}$ & $\begin{array}{l}\text { Esophageal Ulcer with } \\
\text { Carcinoma In-Situ }(n=11)\end{array}$ \\
\hline Polyp & Polyp $(n=49)$ & $\begin{array}{l}\text { Hyperplasic } \\
\text { Polyp(n=49) }\end{array}$ & NIL \\
\hline Adenoma/Carcinoma & Adenoma/Carcinoma $(n=26)$ & Carcinoma $(n=26)$ & NIL \\
\hline H. Pylori Gastritis & H. Pylori Gastritis ( $n=196$ ) & $\begin{array}{l}\text { H. Pylori Gastritis } \\
(\mathrm{n}=122)\end{array}$ & $\begin{array}{l}\text { Non-Specific } \\
\text { Gastritis(n=74) }\end{array}$ \\
\hline Hyperplastic Polyp & Hyperplastic Polyp ( $n=69$ ) & $\begin{array}{l}\text { Hyperplastic Polyp } \\
(n=51)\end{array}$ & $\begin{array}{l}\text { Adenomatous } \\
\text { Polyp }(n=18)\end{array}$ \\
\hline $\begin{array}{l}\text { Hiatus Hernia With } \\
\text { Gastric Ulcer }\end{array}$ & $\begin{array}{l}\text { Hiatus Hernia With Gastric } \\
\text { Ulcer }(n=469)\end{array}$ & $\begin{array}{l}\text { Gastric Ulcer } \\
(n=453)\end{array}$ & $\begin{array}{l}\text { Ulcer with Carcinoma } \\
\text { In-Situ }(n=16)\end{array}$ \\
\hline Gastric Ulcer & Gastric Ulcer $(n=480)$ & $\begin{array}{l}\text { Gastric Ulcer } \\
(n=448)\end{array}$ & $\begin{array}{l}\text { Ulcer with Carcinoma } \\
\text { In-Situ }(n=32)\end{array}$ \\
\hline $\begin{array}{l}\text { Gastro Intestinal Stromal } \\
\text { Tumor (Gist) }\end{array}$ & $\begin{array}{l}\text { Gastro Intestinal Stromal Tumor } \\
\text { (Gist) }(n=03)\end{array}$ & $\begin{array}{l}\text { Gastro Intestinal Stromal } \\
\text { Tumor (Gist) }(n=03)\end{array}$ & NIL \\
\hline Adenoma / Carcinoma & Adenoma / Carcinoma $(n=79)$ & Carcinoma $(n=61)$ & Adenoma $(n=18)$ \\
\hline Lymphoma & Lymphoma(n=05) & Lymphoma(n=05) & NIL \\
\hline Duodenitis & Duodenitis ( $n=381$ ) & $\begin{array}{l}\text { Non-Specific } \\
\text { Duodenitis }(n=381)\end{array}$ & $\begin{array}{l}\text { Non-Specific Duodenitis } \\
(n=381)\end{array}$ \\
\hline Celiac Disease & Celiac Disease $(n=87)$ & $\begin{array}{l}\text { Celiac Disease } \\
(n=49)\end{array}$ & $\begin{array}{l}\text { Non-Specific Duodenitis } \\
(n=38)\end{array}$ \\
\hline Giardia & Giardia $(n=08)$ & $\begin{array}{l}\text { Giardiasis duodenum } \\
(\mathrm{n}=05)\end{array}$ & $\begin{array}{l}\text { Non-Specific Duodenitis } \\
(n=03)\end{array}$ \\
\hline $\begin{array}{l}\text { Neuroendocrine } \\
\text { Tumor (NET) }\end{array}$ & $\begin{array}{l}\text { Neuroendocrine Tumor (NET) } \\
(n=06)\end{array}$ & $\begin{array}{l}\text { Neuroendocrine Tumor } \\
\text { (NET) }(n=04)\end{array}$ & Carcinoma $(n=02)$ \\
\hline Carcinoma & Carcinoma $(n=29)$ & Carcinoma $(n=27)$ & $\begin{array}{l}\text { Neuroendocrine Tumor } \\
(\mathrm{NET})(\mathrm{n}=02)\end{array}$ \\
\hline
\end{tabular}


Out of the 3978 lesions, 134 cases were diagnosed as carcinoma on endoscopy and they were confirmed by histopathological examination. However, there were different histological variants, Squamous cell carcinoma (SCC) was the dominant histological variant in esophagus and Adenocarcinoma was commonest variant in the gastric cavity and the least common was Signet ring cell Adenocarcinoma.
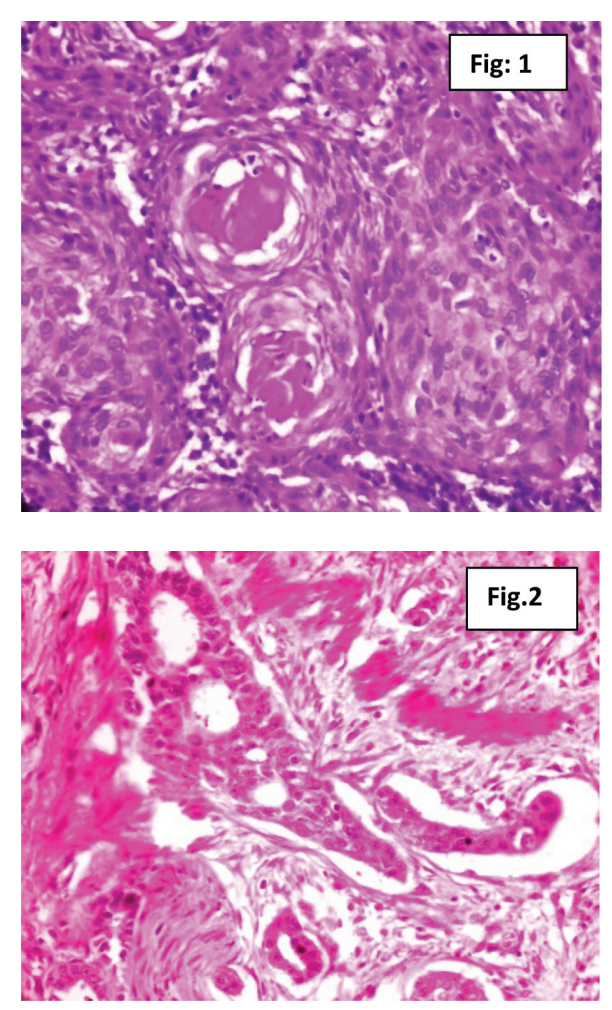

Figure 1: Microphotograph showing squamous cell carcinoma with keratin pearls, cellular atypia, high Nuclear-Cytoplasmic ration and scant cytoplasm. Mitotic figures also seen 1-2/HPF

Figure 2: Microphotograph showing Adenocarcinoma with glandular epithelium showing atypia with high Nuclear Cytoplasmic ratio and scant cytoplasm. Infiltration of the stroma with the atypical cells also seen.

\section{Discussion:}

Gastro-Intestinal problems are becoming more and more common these days due to the consumption of stored and processed food and many patients are presenting to the clinicians with the symptoms of dyspepsia, nausea and vomiting, epigastric discomfort and heart burn. Good clinical, endoscopic findings and histopathological examination of the biopsied lesion gives the accurate diagnosis of the lesion and useful for the better treatment. There is a significant requirement to detect these malignant lesions at an initial stage and differentiate them from the various benign and inflammatory conditions that afflict the upper GIT and may present with the overlapping symptoms.
In this present study, males $2689(67.6 \%)$ and 1289 were females (32.4\%), which is in close tandem with the studies done by the authors Hirachand et al, Veenaa Venkatesh et al and Rani $D$ et al ${ }^{[3,4 \text { and } 5] \text {. }}$

Maximum number of cases was inflammatory and benign in nature; mainly chronic non-specific Esophagitis or Reflux Esophagitis $(75.75 \%)$ was the commonest diagnosis. All neoplastic cases constituted (24.5\%), $1.9 \%$ cases were malignancies and the most common histological variant in the esophagus was squamous cell carcinoma and one case was adenocarcinoma. All the suspicious malignancies were diagnosed as carcinomas by the Endoscopist. These findings were similar to studies done by the authors Abilash SC et al, Krishnappa $R$ et al and Sheikh BA et al ${ }^{[6,7} 7$ and 8$]$. In one more study done by Qureshi N A et al, $70.20 \%$ incidence was adenocarcinoma among the esophageal cancers diagnosed, $23.1 \%$ were squamous cell carcinoma, $1.35 \%$ were signet ring cell carcinoma, $2.70 \%$ were anaplastic cancers and $2.70 \%$ undifferentiated cancers with neuro-endocrine differentiation ${ }^{[9]}$.

In the present study, most common gastric lesion was nonspecific gastritis which is in close relation with the studies done by Bhatty et al ${ }^{[10]}$. The second most common histopathological diagnosis among the gastric biopsies were H.pylori gastritis which is in close correlation with the study done by Sheikh BA et al also found $\mathrm{H}$. pylori gastritis (20.4\%) which was the commonest non-neoplastic lesion in their study ${ }^{[8]}$.

In this study, among 1909 gastric biopsies 79 cases were diagnosed as malignancies, 03 cases were diagnosed as GIST and 05 cases were diagnosed as Lymphoma (4.55 \%).In a study conducted by Sk Md Jaynul Islam et al, 73 endoscopic gastric biopsies $45.20 \%$ were diagnosed as malignant and all were adenocarcinoma of different grades ${ }^{[11]}$, while Rashmi $\mathrm{K}$ et al found $27.94 \%$ malignant lesions among 68 gastric endoscopic biopsies and all were adenocarcinoma ${ }^{[12]}$; Bhatty et al got gastric carcinoma in only $1.9 \%$ cases of a large series of 1076 upper GIT endoscopy biopsies ${ }^{[10]}$.

In our study among the histologically confirmed adenocarcinoma cases $(72.2 \%)$ had concordance of $69.69 \%$ with clinical diagnoses established by the endoscopist while Kazi Jl et al found $88.8 \%$ concordance for gastric carcinoma ${ }^{[13]}$.

In our study, non-specific duodenitis was most common which is in correlation with the study done by Kazi $\mathrm{Jl}$ et al and in contrast with the study done by Sk Md Jaynul Islam et al where duodenal hyperplasic polyps were the commonest pathology among the duodenal biopsies both Endoscopically as well as histopathologically ${ }^{[11,13]}$.

Duodenal malignancies in the present study was $0.5 \%$ only, in the study done by Sk Md Jaynul Islam et al duodenal malignancies were $13.33 \%$, while Kazi Jl et al reported zero duodenal malignancy among 146 duodenal biopsies done ${ }^{[13]}$. 
To summarize, in this study, over all, stomach was found to be the most common site for upper gastrointestinal tract lesions followed by esophagus and duodenum. This study can be closely matched with the findings of Rashmi K et al and Gulia SP et al ${ }^{[5,12, \text { and } 14]}$.

\section{CONCLUSION}

Endoscopy is an important tool which helps in direct visualization of the lesion and to establish a diagnosis of wide spectrum of neoplastic and non-neoplastic lesions; however endoscopy clubbed with the histopathology findings gives the most accurate diagnosis which helps in the early diagnosis and treatment. Endoscopy is most useful in the lesions of the stomach as the incidence of various diseases is more in the stomach.

\section{REFERENCES}

1. "Endoscopy". British Medical Association Complete Family Health Encyclopedia. Dorling Kindersley Limited. 1990.

2. Edmonson JM (March 1991). "History of the instruments for gastrointestinal endoscopy". Gastrointestinal Endoscopy. 37 (2 Suppl): S27-56.

3. Hirachand et al. Histopathological spectrum of upper gastrointestinal endoscopic biopsies JBPKIHS 2018;1(1),67-74

4. Veenaa Venkatesh, Riyana R Thaj. Histopathological Spectrum of Lesions in Gastrointestinal Endoscopic Biopsies: A Retrospective Study in a Tertiary Care Center in India. World J Pathol 2019; 8:1-6.

5. Rani D, Bhuvan S, Gupta A. A study of morphological spectrum of upper gastrointestinal tract lesions by endoscopy and correlation between endoscopic and histopathological findings. Indian J Pathol Oncol 2019;6(1):28-34.

6. Abilash SC, Hasaf K, Gitanjali MM, Shreelaxmidevi S, Balamuruganvelu S. Histopathologic spectrum of upper gastrointestinal tract mucosal biopsies: A retrospective study. Sch. J. App. Med. Sci. 2016; 4(5): 1807-13.

7. Krishnappa R, Horakerappa MS, Mangala Ali Karar, GouriMangala. A study on histopathologic spectrum of upper gastrointestinal tract endoscopic biopsies. Int J Medical Res Health Sciences 2013; 2(3): 418-24.

8. Sheikh BA, Hamdani SM, Malik R. Histopathological spectrum of lesions of upper gastrointestinal tract- A study of endoscopic biopsies. Global Journal of Medicine and Public Health 2015; 4(4): 1-8.
9. Qureshi NA, Hallissey MT, Fielding JW. Outcome of Index Upper Gastrointestinal Endoscopy in Patients Presenting with Dysphagia in a Tertiary Care Hospital-A 10 Years Review. BMC Gastroenterology. 2007, 7:43.

10. Bhatty AS, Shaikh NA, Zahir N, Akhter SS, Vaswani AS, Manzoor H. Histopathologic Spectrum of Upper Gastrointestinal Endoscopies. Medical Channel. 2009;15(4):11-14.

11. Sk Md Jaynul Islam, A S M Mostaque Ahmed, M Shahab Uddin Ahamad, SAMMA Hafiz. Endoscopic and Histologic Diagnosis of Upper Gastrointestinal Lesions, Experience in a Port City of Bangladesh. Chattagram Maa-O-Shishu Hospital Medical College Journal. Volume 13, Issue 3, September 2014.

12. Rashmi K, Horakerappa MS, Karar A, Mangala G. A Study on Histopathological Spectrum of Upper Gastrointestinal Tract Endoscopic Biopsies. Int J Med Res Health Sci. 2013;2 (3):418-424. DOI: 10.5958/j.2319-5886.2.3.073.

13. Kazi JI, Alam SM, Kazi AM, Anwar A, Shamsi Z. Correlation of Endoscopic and Histologic Diagnosis in Upper Gastrointestinal lesions. JPMA. 1990;40(12):281-283.

14. Gulia SP, Chaudhary M, Noorunnisa N, Balagurunathan K. Interpretation of upper gastrointestinal tract mucosal biopsies-A study conducted in teaching hospital in Puducherry, India. Int J Med Health Sci 2012; 3:17-24.

How to cite this article : D. Santhi Kiran,Y.R.Nagarjuna Kumar. Diagnosis of upper gastrointestinal lesions by endoscopy and its correlation with histopathology. Perspectives in Medical Research 2020; 8 (2):100-105. DOI : 10.47799/pimr.0802.21

Sources of Support: Nil, Conflict of interest: None declared 